\title{
KERAGAAN COPEPODA CYCLOPOIDA: Apocyclops sp. PADA KONDISI KULTUR
}

\author{
Philip Teguh Imanto dan Gede Suwarthama Sumiarsa \\ Balai Besar Riset Perikanan Budidaya Laut \\ Jl. Br. Gondol, Kec. Gerokgak, Kab. Buleleng-Kotak Pos 140, Singaraja, Bali 81101 \\ E-mail:philip_imanto@yahoo.co.id
}

(Naskah diterima: 26 Januari 2010; Disetujui publikasi: 20 Agustus 2010)

\begin{abstract}
ABSTRAK
Copepoda pada dasarnya adalah udang berukuran mikroskopik yang menjadi rantai pakan alami yang penting di perairan bebas. Investigasi jenis-jenis copepod lokal akan membantu menyiapkan informasi untuk pengembangan budidayanya sebagai jasad pakan alami. Penelitian dilakukan dengan mengkoleksi jenis Cyclopoida lokal perairan pantai Gerokgak, Buleleng, Bali, diisolasi dan dikembangbiakkan dengan pakan kombinasi antara alga Nannochloropsis oculatta, tepung terigu, ragi roti, dan hati ayam dalam tangki beton $5 \mathrm{~m}^{3}$. Tiga ratus individu Cyclopoida yang membawa telur ditempatkan pada tiga wadah kultur bervolume satu liter. Pengamatan pada pertumbuhan individu dilakukan dengan sampling setiap hari dan setiap dua hari untuk melihat perkembangan telurnya. Jenis Cyclopoida lokal termasuk famili Cyclopidae dan genus Apocyclops spp. Kecepatan pertumbuhan mencapai $20 \mu \mathrm{m}$ setiap harinya, dan dari fase copepodit mencapai ukuran dewasa membawa telur dianalisis selama 12 hari, perkembangan telur memerlukan waktu maksimal 10 hari, sehingga estimasi siklus umur minimal adalah 22 hari. Produktivitas rata-rata telur Apocyclops spp. pada penelitian ini diestimasi sebanyak 36 (minimum16-maksimum 65) butir per individu betina. Penelitian kultur lebih lanjut difokuskan pada optimalisasi suhu, salinitas, oksigen terlarut pada media hingga optimalisasi pada jenis pakan.
\end{abstract}

KATA KUNCl: Copepoda, Cyclopidae, Apocyclops spp., morfologi, pertumbuhan, produktivitas telur

ABSTRACT: Performance of Copepod Cyclopoida: Apocyclops spp. in culture condition. By: Philip Teguh Imanto and Gede Suwarthama Sumiarsa

Copepod, a microscopic shrimp, is an important member in natural food chain in waters. Investigating the types of local copepod will provide valuable information for the development of other natural live feed culture. The research was carried out by collecting local Cyclopoida species from Gerokgak coastal waters, Buleleng RegencyBali, isolated and cultured with combination feed of algae Nannochloropsis oculatta, wheat flour, yeast bread and chicken liver in $5 \mathrm{~m}^{3}$ concrete tank. Three hundred individuals of Cyclopoida carrying eggs were placed in three beaker glasses of oneliter culture volume. An observation on the individual growth was done by daily sampling and every two days to see the development of the eggs. The type of local Cyclopoid was classified as Cyclopidae family in the genus of Apocyclops spp. The growth rate reached 20 im per day, and from copepodite to adult carrying eggs took 12 days, the egg development took maximum 10 days, and the estimate of the minimum age cycle was 22 days. The average productivity of egg of Apocyclops spp. in this study was estimated to be 36 (min. 16-max. 65) eggs per female. Further culture studies 
focusing on the optimization of temperature, salinity, dissolved oxygen in the media and nutritional aspects, need to be further studied.

\section{KEYWORDS: Copepod, Cyclopidae, Apocyclops spp., morphology, growth, eggs productivity}

\section{PENDAHULUAN}

Copepoda pada dasarnya adalah udang berukuran mikroskopik yang menjadi rantai pakan alami yang penting di perairan bebas (marine food web) (Rhodes, 2000) mulai dari perairan pantai hingga perairan dalam, dari daerah tropis hingga perairan dingin di kutub. Di samping untuk kepentingan akuakultur, penelitian pada copepoda juga sangat bermanfaat untuk memahami pola siklus karbon dan material fluxes pada semua bentuk perairan, yang dapat bermanfaat sebagai indikator-indikator penting dari terjadinya perubahan massa air hingga perubahan iklim (Razouls et al., 2005; 2009).

Copepoda termasuk kelompok udang "entomostracan" ditandai dengan ukuran yang kecil, memiliki tubuh yang terdiri atas kepala (head), dada (thorax), dan perut (abdomen); kepala dan dada menyatu secara halus membentuk tubuh bagian depan (formamain); dan memiliki mata yang sederhana di tengah (median or nauplius eye).

Beberapa spesies merupakan parasit bagi ikan (Newell \& Newell, 1986) yaitu: Notodelphyoida, Monstrilloida, Caligoida, dan Lernaeopodaida, sedang yang biasa dibudidayakan adalah bentuk pelagik dan benthic yaitu: Calanoida (lebih banyak sebagai planktonik), Cyclopoida (planktonik dan benthik), dan Harpacticoida (benthik), tiga kelompok ini diketahui dapat dimanfaatkan sebagai sumber pakan alami pada pemeliharaan larva ikan dan udang (Farhadian et al., 2009; Rhodes, 2000).

Kelompok copepoda sangat memungkinkan untuk menggantikan peranan rotifer dan Artemia sebagai pakan larva ikan laut sesuai dengan ukurannya, yang bervariasi mulai dari $60 \mu \mathrm{m}$ sampai lebih dari $2 \mathrm{~mm}$ dan yang secara alami mengalami blooming musiman.

Penelitian tentang kemungkinan copepoda dibudidayakan sebagai sumber pakan alami telah dilakukan, di antaranya dengan pemilihan jenis potensial untuk budidaya laut seperti yang dikerjakan oleh Fleeger (2005), pengamatan pada berbagai faktor yang mempengaruhi sukses pemangsaan larva ikan laut pada copepoda sebagai pakan alami (Chesney, 2005) hingga pemanfaatannya sebagai pakan untuk post larva udang (Farhadian et al., 2009) maupun kerapu macan (Sumiarsa et al., 2006).

Investigasi pada jenis-jenis copepoda yang terdapat di perairan setempat, akan membantu menyiapkan informasi-informasi untuk pengembangan budidayanya sebagai jasad pakan alami pada pemeliharaan larva ikan dan udang.

\section{BAHAN DAN METODE}

Penelitian ini dilakukan dengan mengkoleksi jenis cyclopoida lokal dari perairan pantai Gerokgak Kabupten Buleleng, Bali, kemudian diisolasi dan dikembangbiakkan seperti harpacticoida lokal, yaitu selama kurang lebih 90 hari pada tangki beton bervolume $5 \mathrm{~m}^{3}$ dengan pakan kombinasi antara alga Nannochloropsis oculatta, tepung terigu, ragi roti, dan hati ayam (Imanto et al., 2007). Gaudy \& Guerin dalam Raymont (1983) mengindikasikan penggunaan pelet yang dihaluskan, dan bahan pakan yang bernitrogen tinggi seperti casein, minyak hati ikan cod, dan ragi dapat dimanfaatkan untuk memelihara Tisbe holothuriae. Rhodes (2000) menyatakan bahwa copepoda menangkap dan memangsa fitoplankton, bakteria, maupun detritus.

Khusus pengamatan perkembangan telur digunakan tiga buah beaker glass $1.000 \mathrm{~mL}$. yang diletakkan dalam wadah (Gambar 1), cyclopoida yang membawa telur ditempatkan ke dalam media pemeliharaan sebanyak 100 individu untuk masing-masing wadah dan diberikan Nannochloropsis dengan kisaran $50.000 \mathrm{sel} / \mathrm{mL}$. dalam media penelitian sebagai sumber pakan selama pengamatan.

Data yang dihimpun adalah morfologi copepoda pada awal kegiatan yang dilakukan dengan pendokumentasian 5 sampel copepod dewasa dan dipilih detail terbaik. Setelah masa kultur 90 hari, pembawaan telur, diameter, dan 


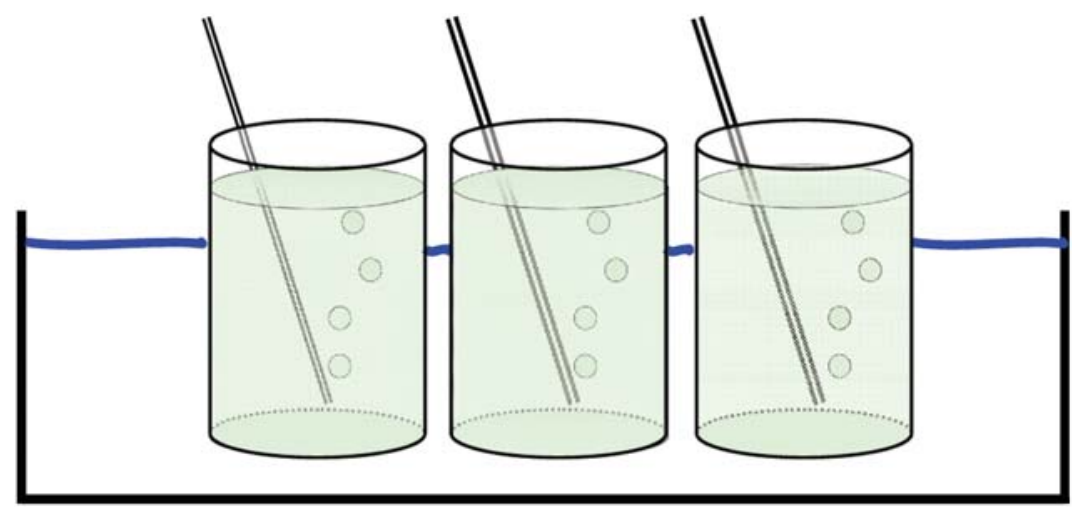

Gambar 1. Desain sarana penelitian dalam sistem terendam

Figure 1. Design of observation apparatus in water bath system

jumlah telur dari populasi penelitian dilakukan dengan mengamati sampel copepod yang bertelur sebanyak 50 individu dari tangki beton. Perkembangan ukuran copepod dewasa dilaksanakan dengan melakukan sampling 30 individu tiap hari pada pukul 11.00 untuk koleksi data ukuran copepoda dewasa (dari tangki beton), dan untuk individu yang membawa telur dilakukan setiap dua hari (dari beaker glass) minimal 5 individu yang masih membawa telur. Metode penelitian ini bersifat deskriptif, pengamatan, pengukuran, dan dokumentasi menggunakan mikroskop binokular dengan keping mikrometer, kamera digital mikroskop dengan perangkat lunak Ulead Photo Exporer 7.0 SE. Untuk pengolahan gambar, data, dan pelaporan dipergunakan perangkat lunak (software) Microsoft ${ }^{\circledR}$ photo editor, Microsoft ${ }^{\oplus}$ Excel, dan Microsoft ${ }^{\circledR}$ Word.

\section{HASIL DAN BAHASAN}

Seperti halnya calanoida, tubuh bagian depan (fore-body) dari cyclopoida memiliki tanda/batas yang jelas dari urosome. Tetapi segmen dada (thoracic segment) yang pertama kadang juga kedua selalu menyatu dengan kepala, segmen dada keenam (terakhir) menyambung pada segmen pertama dari urosome yang mendukung sepasang limbs yang rudimentary. Sehingga selalu nampak hanya ada 4 umumnya 3 segmen dada (thoracic segment) di tubuh bagian depan (forebody). Sambungan bergerak (moveable joint) terletak antara segmen dada ke-5 dan 6 . Urosome memiliki 5 segmen pada betina dan 6 segmen pada jantan ditambah ekor (telson), tetapi beberapa menyatu. Antennae pendek dengan beberapa sambungan (Gambar 2). Kantung telur ada sepasang hampir pada semua jenis. (Newell \& Newell, 1986).

\section{Morfologi}

Hasil pengamatan pada dokumentasi foto bentuk hewan uji yang dihasilkan seperti pada Gambar 3, secara umum menunjukkan kesamaan dengan ciri-ciri umum kelompok cyclopoida seperti yang tertera pada Gambar 2. Hewan uji ini memiliki tanda segmen dada (thoracic segment) yang menyatu dengan kepala, segmen dada keenam (terakhir) menyambung pada segmen pertama dari urosome yang memiliki 5 segmen, Antennae pertama pendek dengan beberapa sambungan dan memiliki sepasang kantung telur. (Newell \& Newell, 1986).

Hasil pengamatan morfologi yang telah dilakukan dan membandingkan dengan beberapa kepustakaan (Newell \& Newell, 1986; Alberti et al., 2003; 2009; Chullasorn et al., 2008), dapat dipastikan susunan taksonomi dari hewan uji adalah sebagai berikut:
Filum : Arthropoda
Sub filum : Crustasea
Class : Maxilloppoda
Sub class: Copepoda
Ordo : Cyclopoida
Famili : Cyclopidae

Dari pengukuran panjang total (dari ujung depan carapace hingga ujung belakang caudal ramus) prosoma + urosoma (Gambar 2), didapatkan rata-rata $979.4 \mu \mathrm{m}$ (850-1.220 


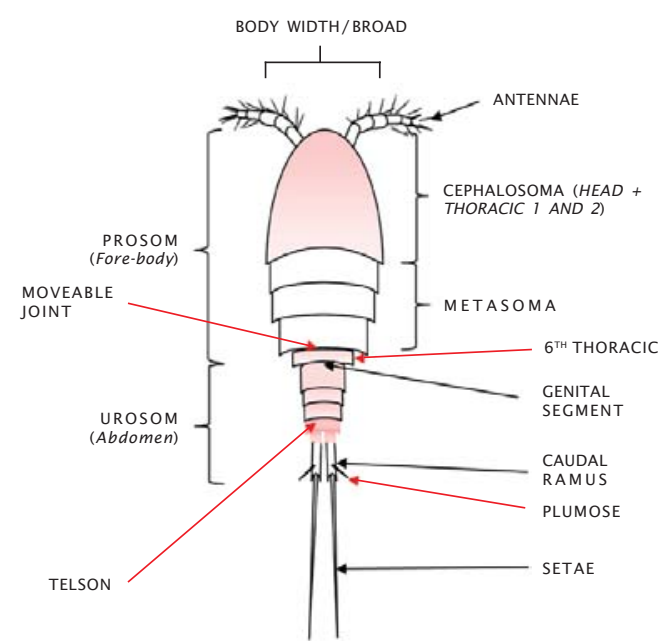

Gambar2. Morfologi umum dari copepoda cyclopoida

Figure 2. General morphology of cyclopoid copepoda

$\mu \mathrm{m})$, hasil ini menyerupai dengan ukuran Cyclopidae (Apocyclops ramkhamhaengi sp. nov) yang diteliti oleh Chullasorn et al. (2008) sebesar 950-1.030 $\mu \mathrm{m}$.

Dengan perbesaran foto dokumentasi, dapat digambar ulang bagian detil Antennae pertama (Gambar 3a), dan diketahui terdiri atas 10-11 segmen (Gambar 3), Teknik yang sama dilakukan pada bagian ekor (caudal ramus), dan diketahui lebar caudal ramus berkisar seperlima dari panjangnya (Gambar 3c). Tidak terdapat bulu halus di bagian dalam caudal ramus dan menurut kunci identifikasi yang dikembangkan oleh Alberti et al. (2003-2009) dikelompokkan pada famili Cyclopidae.

Dari kedua penggambaran detail tersebut bila dibandingkan dengan rincian yang dibuat oleh Chullasorn et al. (2008) memiliki ciri yang sama dengan jenis Apocyclops ramkhamhaengi sp. nov.

Hewan uji yang menjadi objek penelitian ini diyakini tergolong pada genus Apocyclops dan hingga saat ini baru diketahui 3 spesies Apocyclops di kawasan Asia (Botelho, 1999 dalam Chullasorn et al., 2008) sebagai $A$. royi (Lindberg), A. borneoensis (Lindberg), dan A. dengizicus seperti yang digambarkan oleh Lepeshkin (1900) dalam Chullasorn et al. (2008). Jenis A. borneoensis juga menjadi objek

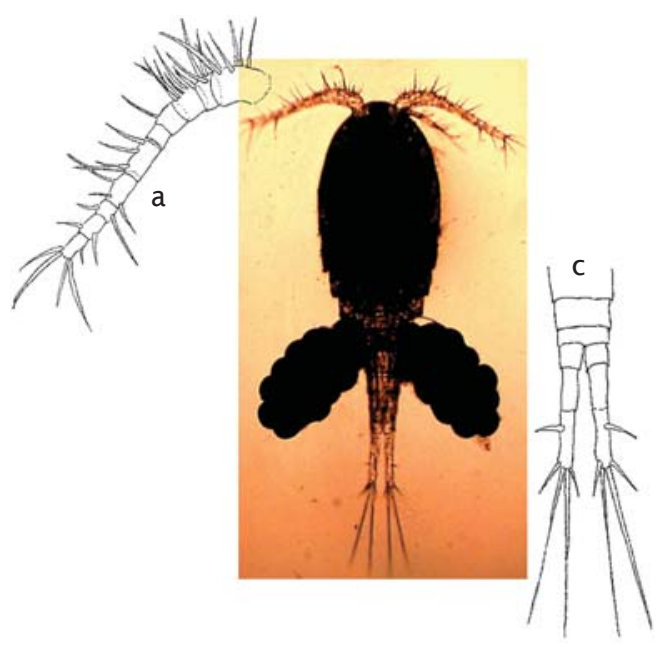

Gambar3. Detil antena dan ekor famili Cyclopidae (Apocyclops sp.)

Figure 3. Detail of antennae and caudal ramus of local Cyclopidae (Apocyclops sp.)

penelitian oleh Sutomo (2007) dan Suantika \& Antarini (2007) tentang pertumbuhan polulasinya.

Gambar 4 adalah tahapan awal dan akhir nauplius dari Apocyclops spp., menurut Farhadian et al. (2009) Apocyclops spp. mempunyai enam tingkatan nauplii $(85-240 \mu \mathrm{m})$ serta lima tingkatan copepodits $(320-680 \mu \mathrm{m})$ sebelum menjadi copepoda dewasa.

Dari keterangan Gambar 4, dapat dipahami bahwa nauplii copepoda banyak dimanfaatkan sebagai jasad pakan awal pada berbagai pemeliharaan larva ikan dan udang karena ukurannya, serta nilai gizinya.

Kandungan asam amino esensialnya (total essential amino acid) antara 57,1-67,8\% dari total amino acid, dengan perimbangan EPA (eicosapentaenoic acid), DHA (docosahexaenoic acid), dan ARA (arachidonic acid) seperti hasil penelitian Farhadian et al. (2008) pada Tabel 1.

\section{Pertumbuhan}

Pertumbuhan individu ditujukan untuk dapat mengetahui kecepatan perkembangan individu dan dugaan pencapaian umur hingga ke ukuran dewasa dan bereproduksi. Data panjang prosoma digunakan sebagai analisis pertumbuhan individu dikarenakan relatif lebih 


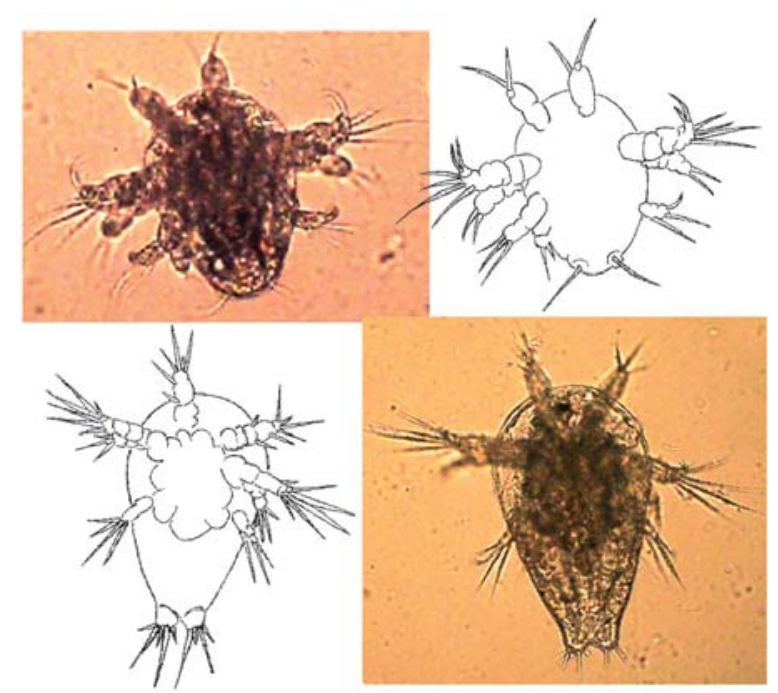

Gambar 4. Nauplii Apocyclops sp. tingkat awal dan akhir

Figure 4. Early and last stage nauplii of Apocyclops sp.

Tabel 1. Perbandingan DHA:EPA:ARA dari Apocyclops dengizicus yang diberi makan Chaetoceros calcitrans, Tetraselmis tetrathele, dan kombinasi keduanya

Table 1. DHA:EPA:ARA ratios of Apocyclops dengizicus fed with Chaetoceros calcitrans $(C)$, Tetraselmis tetrathele $(T)$, and the combination of both (CT)

\begin{tabular}{lc}
\hline \multicolumn{1}{c}{ Diberi pakan (Fed with) } & DHA : EPA : ARA rasio (ratios) \\
\hline Chaetocerous calcitrans & $6.8: 3.0: 1.0$ \\
Tetraselmis tetrathele & $14.0: 5.8: 1.0$ \\
Kombinasi CT $(1: 1$ berdasarkan jumlah) & $11.6: 2.6: 1.0$ \\
Combination CT (1:1 by number) & \\
\hline
\end{tabular}

Sumber (Source): Farhadian et al. (2008)

stabil dan pasti karena pergerakan segmennya terbatas, dibanding panjang total yang akan sangat mudah terjadi bias saat ada pembengkokan abdomen ataupun patahnya caudal ramus. Hasil pengukuran dituangkan pada Gambar 5 untuk periode pengamatan tanggal 9, 11, 12, dan 13 Juni 2007 yang disusun dalam bentuk tabulasi frekuensi kejadian dari kelompok ukuran untuk memudahkan melihat hubungan antara puncakpuncak kelompok ukuran dari 4 kali pengamatan.

Dari hasil pengukuran panjang prosoma diketahui nilai terkecil adalah $300 \mu \mathrm{m}$ dan yang terbesar adalah $540 \mu \mathrm{m}$. Dari Gambar 5 dapat ditarik tiga garis sejajar yang menghubungkan puncak-puncak populasi menurut kelompok ukuran prosoma, dan garis-garis tersebut memperlihatkan suatu garis pertumbuhan dengan nilai besaran $20 \mu \mathrm{m}$ setiap harinya. Bila diketahui ukuran awal $300 \mu \mathrm{m}$ dan mencapai maksimal $540 \mu \mathrm{m}$, maka diperlukan penambahan panjang sebesar $240 \mu \mathrm{m}$, hal ini berarti dari copepodit tingkatan terakhir hingga menjadi dewasa siap bereproduksi akan memerlukan waktu pertumbuhan maksimal selama 12 hari. Hasil ini menyerupai yang diungkapkan oleh Sutomo (2007) bahwa A. borneoensis pada salinitas 25-35 ppt memerlukan waktu 11 hari hingga 15 hari (45 ppt) untuk mencapai tahapan produksi telur. 


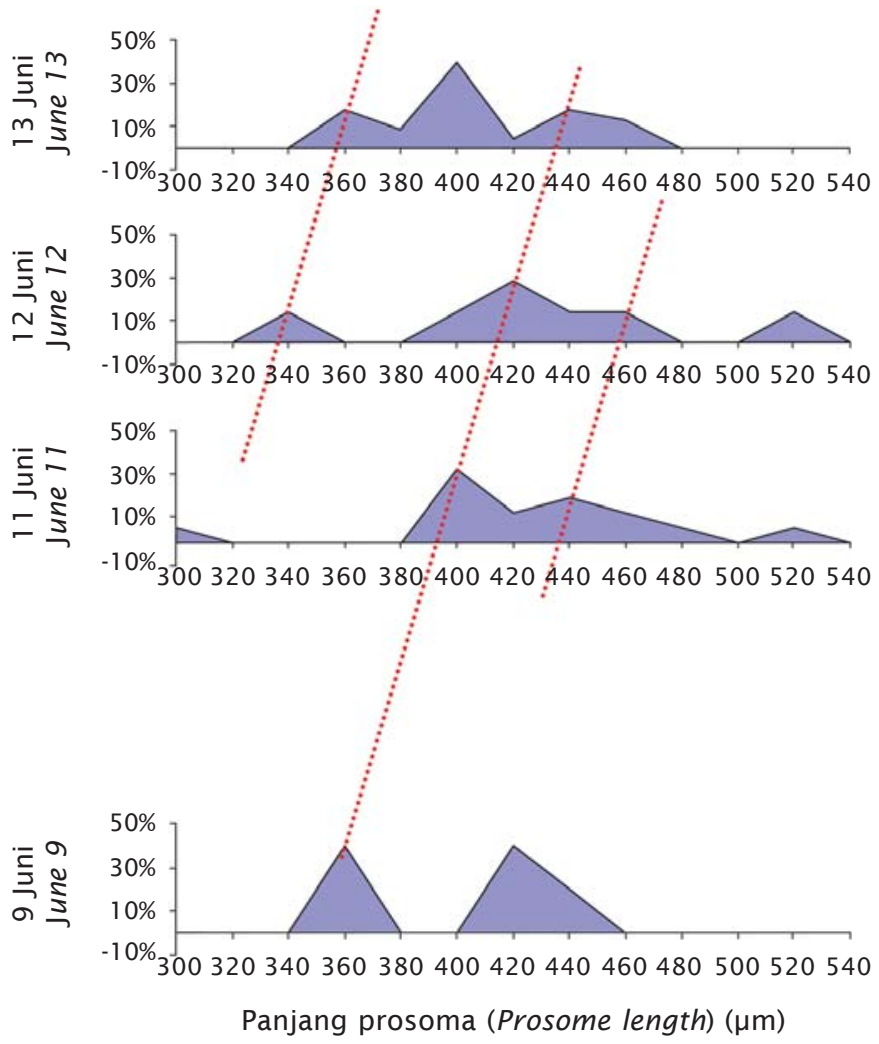

Gambar 5. Perkembangan prosoma dari Apocyclops sp. selama pengamatan

Figure 5. Prosome development of Apocyclops sp. during observation

\section{Produktivitas Telur}

Famili Cyclopidae lokal Gerokgak yang termasuk genera Apocyclops sp. memiliki dua kantung pembawaan telur (Gambar 6a), jumlah telur dari masing-masing kantung belum tentu sama. Jumlah total telur yang mampu diproduksi sangat bervariasi mulai dari 16 hingga 65 butir dari tiap individunya (Gambar 6b), dan ini sangat dipengaruhi oleh kondisi lingkungan maupun nutrisi yang didapatkan oleh individu copepoda tersebut. McKinnon et al. (2003), dalam penelitiannya mendapatkan bahwa produksi telur tertinggi dari calanoid copepod Bestiolina similis adalah 48 butir telur per individu dengan pemberian pakan fitoplankton dinoflagelatta Heterocapsa niei.

Dari Gambar 6b, diketahui variasi ukuran diamater telur Apocyclops sp. Iokal dimulai pada ukuran $50 \mu \mathrm{m}$ dan akan mencapai telur matang $100 \mu \mathrm{m}$, ukuran ini tidak terlalu jauh berbeda dengan ukuran diamater telur rotifer dengan kisaran 60-80 $\mu \mathrm{m}$ seperti terlihat pada Gambar 6a.

\section{Perkembangan Embrio}

Dari Gambar 7 terlihat pola grafis yang searah dari jumlah telur berdasarkan diameternya. Hal ini menunjukkan adanya perkembangan embrio di dalam telur yang menyebabkan membesarnya telur dan ini sesuai dengan yang diungkapkan oleh Nielsen et al. (2002) bahwa telur-telur yang berada dalam kantung berkembang dengan periode dan fase yang sama/searah (synchronously) hingga menetas.

Untuk mengetahui kecepatan berkembangnya telur dilakukan analisis pada distribusi frekuensi kejadian berdasarkan 

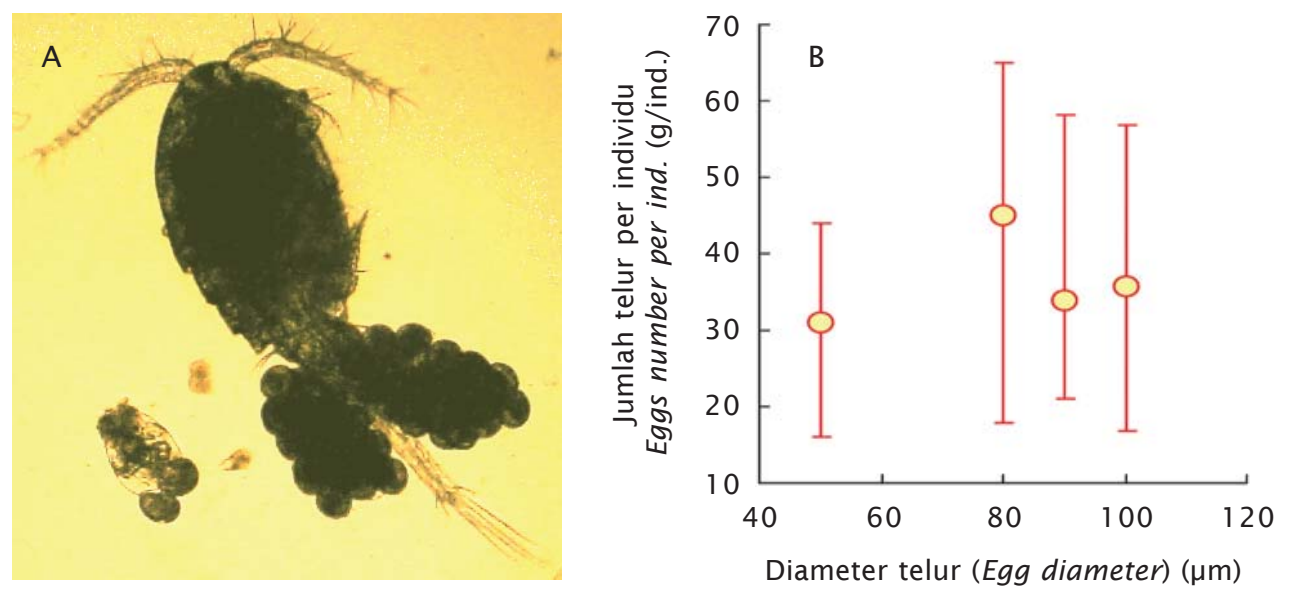

Gambar 6. Pembawaan telur Apocyclops sp. dan produktivitasnya

Figure 6. Apocyclops sp. carrying eggs and it's productivity profile

diameter telur dengan tiga kali pengamatan dengan interval dua hari seperti ditampilkan pada Gambar 8.

Dari Gambar 8 terlihat hubungan yang searah dari beberapa puncak kelompok diameter telur Apocyclops sp. dari tiga waktu pengamatan, dan terlihat pola perkembangan telur dari $80 \mu \mathrm{m}$ mencapai $90 \mu \mathrm{m}$ dalam waktu dua hari dan dengan waktu yang sama menjadi $100 \mu \mathrm{m}$, sehingga telur diduga berkembang membesar dengan kecepatan $5 \mu \mathrm{m}$ per harinya. Diameter awal telur Apocyclops sp. rata-rata $50 \mu \mathrm{m}$ dan mencapai rata-rata $100 \mu \mathrm{m}$ dalam waktu 10 hari dengan perhitungan kecepatan membesar $5 \mu \mathrm{m}$ per hari, sehingga dapat diasumsikan masa inkubasi telur Apocyclops sp. berkisar 10 hari.

\section{Umur Siklus}

Dari data dan analisis tentang umur pertumbuhan Apocyclops spp. sampai bereproduksi (maksimal 12 hari) dan umur perkembangan embrio (maksimal 10 hari), dapat diduga bahwa satu siklus perkembangan Copepoda: Apocyclops spp. minimal memerlukan waktu 22 hari ditambah umur perkembangan nauplii dan copepodit. Jung et al. (1999) menjelaskan puncak pembawaan telur Apocyclops sp. pada penelitiannya terjadi pada hari keenam dan ke-28, yang menun-jukkan adanya interval selama 22 hari untuk proses inkubasi telur-penetasan-tahapan nauplii dan copepodit hingga menjadi dewasa untuk siap bertelur. Kecepatan siklus perkembangan
Copepoda diduga sangat dipengaruhi oleh suhu maupun salinitas media di samping jenis nutrisi pakannya.

Suhu media kultur memiliki peranan penting pada perkembangan individu copepoda seperti yang diungkapkan oleh Mohamed et al. (2008) bahwa perkembangan menjadi dewasa lebih pendek pada musim panas (summer) daripada musim dingin (winter), dan menurut Suantika \& Antarini (2007), suhu optimum untuk Apocyclops borneoensis adalah $33^{\circ} \mathrm{C}$ dengan salinias 20\%. Dan menurut Sutomo (2007), dalam penelitiannya menyimpulkan bahwa pada salinitas $15 \%$ didapatkan pertumbuhan populasi tertinggi yang merupakan hasil dari kecepatan pertumbuhan individunya untuk menjadi dewasa dan bereproduksi.

Produktivitas rata-rata telur Apocyclops spp. pada penelitian ini diestimasi sebagai 36 (16-65) butir per individu betina, dan bila dikaitkan dengan siklus (minimal) 22 hari berarti produktivitas Apocyclops spp. per hari hanya 1-2 butir telur, yang lebih kecil bila dibandingkan dengan kemampuan rotifer memproduksi rata-rata 2-3 butir per individu dengan siklus hidup 24-36 jam.

\section{KESIMPULAN}

Apocyclops spp. dapat dipelihara dan bertumbuh pada kondisi kultur dengan berbagai jenis kombinasi pakan pada tangki besar $\left(5 \mathrm{~m}^{3}\right)$ maupun dalam media alga Nannochloropsis dengan wadah beaker glass. 


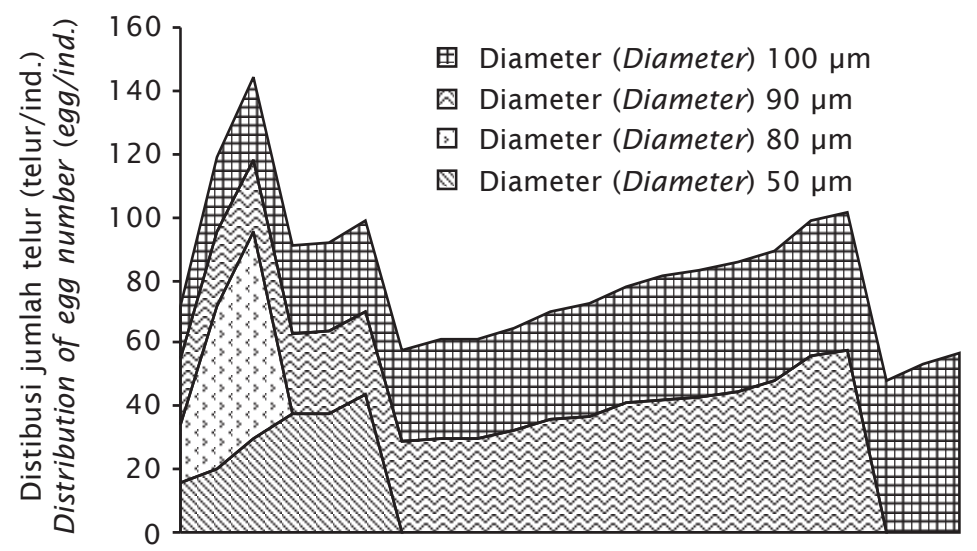

Gambar 7. Grafis sebaran jumlah telur Apocyclops sp. berdasarkan diameter telur

Figure 7. Graphical distribution of eggs number of Apocyclops sp. based on egg diameter
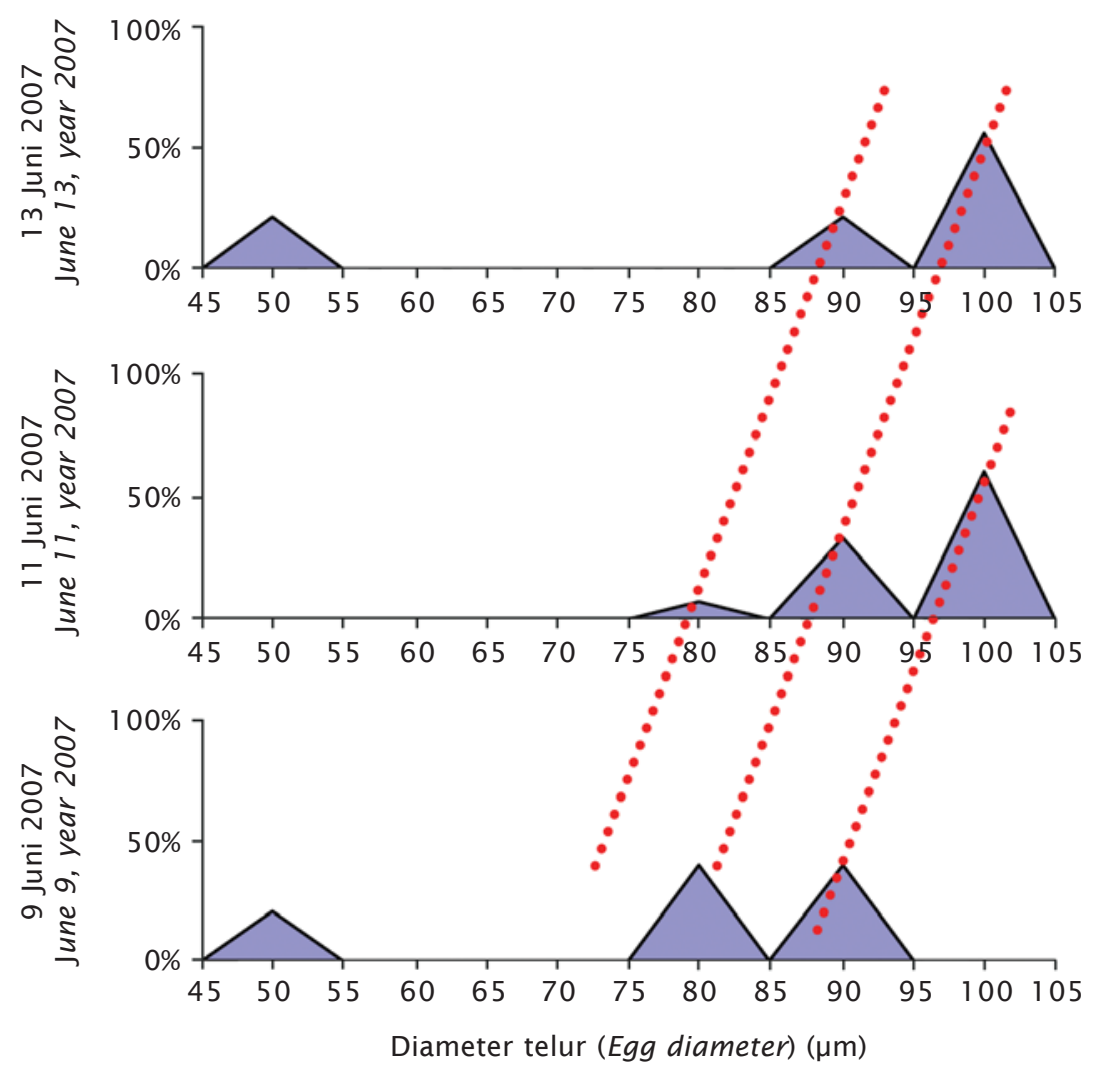

Gambar 8. Histogram persentase telur menurut diameternya pada tiga waktu pengamatan

Figure 8. Histogram of egg percentage based on egg diameter during threeobservation periods 
Pertumbuhan dari fase copepodit terakhir hingga dewasa siap bertelur diperhitungkan selama 12 hari dan masa perkembangan embrio 10 hari, sehingga diasumsikan bahwa siklus minimal dari hewan uji ini adalah 22 hari ditambah dengan umur fase nauplii dan copepodit (yang belum teramati).

Dengan memperhatikan tingkat produktivitasnya yang masih lebih rendah dari jasad pakan rotifer, perlu pengembangan penelitian kultur lebih lanjut untuk meningkatkan produktivitasnya maupun memperpendek siklus pertumbuhan populasinya, mulai optimalisasi suhu, salinitas, oksigen terlarut, dan jenis pakan.

\section{DAFTAR ACUAN}

Aliberti, M.A., Allan, E., Allard, S., Bauer, D.J., Beagen, W., Bradt, S.R., Carlson, B., Carlson, S.C., Doan, U.M., Godkin, W.T., Greene, S., Haney, J.F., Kaplan, A., Maroni, E., Melillo, S., Murby, A.L., Smith (Nowak), J.L., Ortman, B., Quist, J.E., Reed, S., Rowin, T., Schmuck, M., \& Stemberger, R.S. 2003-2009 An Image-Based Key To The Zooplankton Of The Northeast (USA). Department of Biological Sciences. University of New Hampshire, Durham, NH 03824 USA. Available at http:/ /cfb.unh.edu/CFBkey/html/index.html [Accessed October 16, 2009]

Chesney, E.J. 2005. Copepods as Live Prey: A Review Factors That Influence the Feeding Success of Marine Fish Larvae. In Copepods in Aquaculture by Lee, C.S., O'Bryen, P.J., \& Marcus, N.H. (Eds.). Blackwell Publishing, p. 133-150.

Chullasorn, S., Kangtia, P., Pinkkaew, K., \& Ferrari, F.D. 2008. Apocyclop ramkhamhaengi sp.nov. (Copepoda: Cyclopoida) in a Culture Originating frm Brackish Waters of Chang Island, Trat Province, Thailand. Zoological Studies, 47(3): 326-337, accessed from http://zoolsud.sinica.edu.twl./journals/47.3/326.pdf. 29 Oct. 2009.

Farhadian, O., Yusoff, F.M., \& .Mohamed, S. 2008. Nutritional Values of Apocyclops dengizicus (Copepoda: Cyclopoida) fed Chaetoceros calcitrans and Tetraselmis tetrathele. (An abstract). Aquaculture Research, 40(1): 74-82, Blackwell Publishing. accessed Oct. 3. 2009 from: http:// www.ingentaconnect.com/content/bsc/ ares $/ 2008$

Farhadian, O., Yusoff, F.M., Mohamed, S., \& Saad, C.R. 2009. Use of Cyclopoid Copepod
Apocyclops dengizicus as Live Feed for Penaeus monodon Postlarvae. J. of The World Aquaculture Society, 40 (1): 22-32 (accessed Oct. 3. 2009 from: http:// www3.interscience.wiley.com/journal/ 121644414).

Fleeger, J.W. 2005. The Potential to Mass-culture Harpacticoid Copepods for Use as Food for Larval Fish. In Copepods in Aquaculture by Lee, C.S., O’Bryen, P.J., \& Marcus, N.H. (Eds). Blackwell Publishing, p. 11-24.

Imanto, P.T., Sumiarsa, G.S., \& Suastika, M. 2007 Preliminary Study on Population Dynamic of Harpacticoid Copepod Euterpina acutifrons in Culture Condition. Indonesian Aquaculture J., 2 (2): 133-139.

Jung, M.M., Kim, H.S., Rho, S., Rumengan, I.F.M., \& Hagiwara, A. 1999. The Culture of Freeswimming Copepod Species Apocyclops sp. (Copepod: Cyclopoida) by Baking Yeast. J. of Aquaculture, 12(4): 303-307, Accesed from www.koreascience.or.kr October 29, 2009.

McKinnon, A.D., Duggan, S., Nichols, P.D., Rimmer, M.A., Semmens, G., \& Robino, B. 2003. The potential of tropical paracalanid copepods as live feeds in aquaculture. Aquaculture, 223: 89-106, accessed from www.elsevier.com/locate/aqua-online

Mohamed, H.H.; Salman, S.D., \& Abdullah, A.A.M. 2008. Some Aspect of the Biology of two Copepods: Apocyclops dengizicus and Mesocyclops isabellae from a Pool in Garmat - Ali Basrah, Iraq. Turkish J. of Fisheries and Aquatic Sciences, 8: 239-247, accessed from http://www.trjfas.org/pdf/issue 8_2/239_247.pdf. Nov. 12, 2009.

Newell, G.E. \& Newell, R.C. 1986. Marine Plankton a practical guide. Hutchinson \& Co. Publisher, Great Britain, 245 pp.

Nielsen, T.G., Møller, E.F., Satapoomin, S., Ringuette, M., \& Hopcroft. R.R. 2002. Egg hatching of the cyclopoid copepod Oithona similis in arctic and temperate waters. (an poster) Marine ecology. Accesed September 3, 2009 at http://globec.oce.orst.edu/ reports/si_mtgs/si_nov01/ si01_hop_01.pdf.

Raymont, J.E.G. 1983. Plankton and Productivity in The Ocean. $2^{\text {nd }} . e d$. Vol 2. Zooplankton. Pergamon Press. Great Britain, 824 pp.

Razouls, C., de Bovée, F., Kouwenberg, J., \& Desreumaux, N. 2005-2009. Diversity and Geographic Distribution of Marine Planktonic Copepods. Available at http:// 
copepodes.obs-banyuls.fr/en [Accessed October 16, 2009]

Rhodes, A., 2000. Pods Delicious and Nutritious. Wet Web Media .com. accessed from www.wetwebmedia.com/ca/volume_2/ cav2i1/Pods/pods.html oct.10.2009.

Suantika, G. \& Antarini, R.R. 2007. The Optimatization of Temperature, Salinity, and Type of Food for Marine Copepoda (Apocyclops borneoensis) Culture. International Conference on Mathematics and Natural Science (ICMNS), 23-30 November 2006. Proceeding JBPTIT / 2007-02-19. Accessed November 3, 2009 at http:// digilib.sith.itb.ac.id/go.php?id=jbptibbi-gdlproc-2006-gedesuanti
Sumiarsa, G.S., Susanto, B., Suastika, M., \& Imanto, P.T. 2006. Pertumbuhan dan Sintasan Fase Awal Larva Ikan Kerapu Macan, Epinephelus fuscoguttatus Dengan Pakan Alami Nauplii Kopepoda, Harpacticoid Tisbe holothuriae dan Rotifer. Prosiding Konferensi Akuakultur Indonesia. Inovasi teknologi Menuju Industri Akuakultur Global. MAI, UNDIP Semarang, hlm. 12-15.

Sutomo. 2007. Pertumbuhan Populasi Kopepoda, Apocyclops borneoensis Pada Salinitas dan Fotoperiode Yang Berbeda. Oseanologi dan Limnologi di Indonesia, 33: 27-46, diakses pada tanggal 29 Oktober 2009 dari www.oceanografi.lipi.go.id/attachments/536 